\title{
Radiological impact of soil biosolid amendment on maize grown in a Brazilian Ferralsol*
}

\author{
M.A. Wasserman ${ }^{1}$, M.M. Silva1 ${ }^{1}$, D.V. Pérez ${ }^{2}$, E.R. Rochedo ${ }^{1}$, \\ A.C.M. Ferreira ${ }^{1}$, V. Medeiros ${ }^{1}$ and F.P. Padilha ${ }^{1}$ \\ ${ }^{1}$ CNEN/Instituto de Radioproteção e DosimetrialAv. Salvador Allende $s / n^{\circ}$, \\ 22780-160 Recreio, Rio de Janeiro, RJ, Brasil \\ ${ }^{2}$ Centro Nacional de Pesquisa de Solos/EMBRAPA, Rua Jardim Botânico, \\ 1024 CEP 22460-000, Rio de Janeiro, RJ
}

\begin{abstract}
Sewage sludge has predominantly organic composition and can improve soil characteristics, such as fertility and erosion resistance. Therefore, its application as an amendment for agriculture is an adequate alternative for its final disposal. However, there is a lack of information concerning soil enrichment with radionuclides in long-term experiments in tropical areas. Thus, the objective of this study was to determine the impact of soil biosolid amendment on the concentration of ${ }^{210} \mathrm{~Pb},{ }^{226} \mathrm{Ra},{ }^{228} \mathrm{Ra}$, U, Th, and other elements in maize grown in a Brazilian Ferralsol. The results obtained showed that radionuclide concentrations in maize grains were not significantly influenced by either the applied biosolid doses, or biosolid origin, or the interaction of these two factors.
\end{abstract}

\section{INTRODUCTION}

Sewage sludge, an end product of wastewater treatment plants, contain varying concentrations of $\mathrm{N}, \mathrm{P}$, $\mathrm{K}$, and other mineral nutrients necessary for plant growth, but it also contains heavy metals and toxic organic compounds, depending on its origin and processing. The disposal of sewage sludge is presently a great worldwide concern, since its use in soil amendment, incineration, or landfilling can affect the environment.

Traditionally, soil enrichment with radionuclides is connected with industrial and mining activities [1]. The European Commission [2] and the United States [3] observed that biosolids used as fertilizers may be a major source of radionuclides in doses over the limit established for public safety, including the ingestion of foods produced in biosolid-amended soils due to presence of ${ }^{210} \mathrm{~Pb},{ }^{226} \mathrm{Ra}$, ${ }^{228} \mathrm{Ra}$ e ${ }^{210} \mathrm{Po}[2]$.

The present work evaluated the impact of soil biosolid amendment on the concentration of ${ }^{210} \mathrm{~Pb}$, ${ }^{226} \mathrm{Ra},{ }^{228} \mathrm{Ra}, \mathrm{U}$, Th, $\mathrm{Mn}, \mathrm{Zn}, \mathrm{Cu}, \mathrm{Mg}$, and $\mathrm{Ca}$ in maize grown in a Brazilian Ferralsol. Radionuclide uptake will be discussed as a function of biosolid origin, application dose, and soil post-amendment nutrient and metal contents.

\section{MATERIALS AND METHODS}

The impact of the application of biosolids on the concentration of trace elements and nutrients in maize (Zea mays, L.) grown in Ferralsol (clayey Typic Haplustox, American classification) was evaluated in a factorial design $(2 \times 6)$ with randomized blocks in 3 replications. The first factor consisted of two kinds of biosolids: one from the Barueri Wastewater Treatment Plant, located in Metropolitan São Paulo

\footnotetext{
*This work integrates the project on the study the vulnerability of Brazilian soils to radioactive pollutants.
} 
(industrial waste), and another from the Franca Wastewater Treatment Plant, located in the São Paulo countryside (household waste). Both biosolids were supplied by SABESP, the largest Brazilian water company, ready for agricultural application, mainly in maize crops. The second factor consisted of six treatments: 1) an untreated control Ferralsol plot, 2) Mineral fertilization (NPK) based on the Ferralsol soil analysis, 3) biosolid amendment based on its nitrogen content proportional to the amount of $\mathrm{N}$ applied by mineral fertilization $(\mathrm{N})$; 4) two-fold the $\mathrm{N}$ concentration applied in treatment $3(2 \mathrm{~N}), 5$ ) Fourfold the concentration applied in treatment $3(4 \mathrm{~N})$; 6) Eight-fold the concentration applied in treatment $3(8 \mathrm{~N})$. This experiment was conducted in open-field at the environmental unit of Embrapa (Brazilian Enterprise for Agricultural Research), located at Jaguariúna (SP, latitude $22^{\circ} 41^{\prime}$ south, longitude $47^{\circ} \mathrm{W}$. Gr. and altitude of $570 \mathrm{~m})$, where biosolid research has been run since 1998. Soil samples $(0-20 \mathrm{~cm})$ were collected in November 2002. Maize grains were collected in April 2003. Biosolids from the following wastewater treatment plants were also collected and analyzed: Jundiaí, SP, Vila União, To, Brejo Comprido, TO, Alegria, RJ, and Brasília, DF.

The activity of ${ }^{210} \mathrm{~Pb},{ }^{226} \mathrm{Ra}$ and ${ }^{228} \mathrm{Ra}$ in plants, soil, and extracts was determined by radiochemistry analysis. Trace elements and nutrients (Th, U, Mn, $\mathrm{Zn}, \mathrm{Cu}, \mathrm{Fe}, \mathrm{Mg}$, and $\mathrm{Ca}$ ) were determined by ICP-OES (PE OPTIMA 3000). Soil-to-plant transfer factors (TF) were determined as the ratio of radionuclide activity in the edible parts of maize $\left(\mathrm{Bq} \cdot \mathrm{kg}^{-1}\right.$ d.w.) to its activity in the soil $\left(\mathrm{Bq} \cdot \mathrm{kg}^{-1} \mathrm{~d}\right.$.w.). The stock of nutrients, trace elements, and natural radionuclides was calculated by multiplying the concentration of the elements in maize grains by the productivity. The data obtained were evaluated by variance analysis and Tukey mean test at 5\% using SAS software.

\section{RESULTS AND DISCUSSIONS}

The origin of the biosolid did not influence the concentration of ${ }^{210} \mathrm{~Pb},{ }^{228} \mathrm{Ra}$, and $\mathrm{K}$ in the Ferralsol significantly. Nevertheless, the concentration of ${ }^{226} \mathrm{Ra}$ in biosolid-amended Ferralsol increased (Table 1). The differences found were lower than the analytical error for both biosolids (Table 1). However, the concentrations of $\mathrm{Zn}$ and $\mathrm{Cu}$ in the plots applied with the largest amounts of biosolid (8N) increased, mainly for the industrial biosolid (Barueri), whose concentrations of $\mathrm{Cu}$ and $\mathrm{Zn}$ were at least six-fold as high as in amended soils $(8 \mathrm{~N})$ as in the soil control (Table 1). In contrast, the natural concentrations of $\mathrm{Fe}, \mathrm{U}, \mathrm{Th}$, and ${ }^{210} \mathrm{~Pb}$ in plots amended with Franca biosolid were diluted in relation to those of the control plot.

Table 1. Natural soil content of trace elements and macronutrients before and after amendment with mineral fertilizer (NPK) and biosolids.

\begin{tabular}{|c|c|c|c|c|}
\hline & $\begin{array}{l}\text { Ferralsol } \\
\text { (Soil Control) }\end{array}$ & $\begin{array}{l}\text { Ferralsol with } \\
\text { NPK }\end{array}$ & $\begin{array}{l}\text { Variation in the soil } \\
\text { concentration relative to the } \\
\text { control soil after amendment } \\
\text { with Barueri biosolid }(8 \mathrm{~N})\end{array}$ & $\begin{array}{l}\text { Variation in the soil } \\
\text { concentration } \\
\text { relative to the } \\
\text { control soil after } \\
\text { amendment with } \\
\text { Franca biosolid }(8 \mathrm{~N})\end{array}$ \\
\hline$\overline{\mathrm{Cu}\left(\mathrm{mg} \mathrm{kg}^{-1}\right)}$ & $9 \pm 1$ & $12 \pm 2$ & $600 \%$ higher & $78 \%$ higher \\
\hline $\mathrm{Fe}\left(\mathrm{mg} \mathrm{kg}^{-1}\right)$ & $23835 \pm 807$ & $24766 \pm 178$ & $8 \%$ higher & $-10 \%$ lower \\
\hline $\operatorname{Mn}\left(\mathrm{mg} \mathrm{kg}^{-1}\right)$ & $141 \pm 15$ & $167 \pm 16$ & $42 \%$ higher & $-3 \%$ lower \\
\hline $\mathrm{Zn}\left(\mathrm{mg} \mathrm{kg}^{-1}\right)$ & $21 \pm 1$ & $23 \pm 1$ & $762 \%$ higher & $124 \%$ higher \\
\hline $\operatorname{Mg}\left(\mathrm{mg} \mathrm{kg}^{-1}\right)$ & $206 \pm 28$ & $216 \pm 84$ & $5 \%$ higher & $100 \%$ higher \\
\hline $\mathrm{K}\left(\mathrm{mg} \mathrm{kg}^{-1}\right)$ & $538 \pm 125$ & $381 \pm 2$ & $29 \%$ & $-10 \%$ \\
\hline $\mathrm{Ca}\left(\mathrm{mg} \mathrm{kg}^{-1}\right)$ & $821 \pm 112$ & $948 \pm 212$ & $77 \%$ higher & $70 \%$ higher \\
\hline $\mathrm{U}\left(\mathrm{mg} \mathrm{kg}^{-1}\right)$ & $92 \pm 2$ & $99 \pm 3$ & $6 \%$ higher & $-14 \%$ lower \\
\hline $\mathrm{Th}\left(\mathrm{mg} \mathrm{kg}^{-1}\right)$ & $14 \pm 1$ & $15 \pm 0$ & $6 \%$ higher & $-13 \%$ lower \\
\hline${ }^{210} \mathrm{~Pb}\left(\mathrm{~Bq} \mathrm{~kg}^{-1}\right)$ & $47 \pm 11$ & $33 \pm 13$ & $1 \%$ & $-27 \%$ \\
\hline${ }^{226} \mathrm{Ra}\left(\mathrm{Bq} \mathrm{kg}^{-1}\right)$ & $26 \pm 5$ & $28 \pm 2$ & $34 \%$ higher & $18 \%$ higher \\
\hline${ }^{228} \mathrm{Ra}\left(\mathrm{Bq} \mathrm{kg}^{-1}\right)$ & $44 \pm 4$ & $46 \pm 7$ & $-8 \%$ & $5 \%$ \\
\hline
\end{tabular}


In general, the increase in biomass tends to promote the dilution of trace elements in plants. Therefore, to observe the impact of biosolid soil amendment without the relative dilution of the productivity, we calculated the stock of the studied elements. This approach demonstrated a two- or three-fold increase in the stocks of $\mathrm{Zn}, \mathrm{Cu}, \mathrm{Mn}, \mathrm{Ca}$, and $\mathrm{Mg}$ in maize after biosolid soil amendments $(1 \mathrm{~N}, 2 \mathrm{~N}, 4 \mathrm{~N}$, or $8 \mathrm{~N}$ ) when compared with the Ferralsol control and NPK-amended soils (Figures 1 and 2). However, if the increase in concentrations of these elements in soil due to biosolid amendment is partially responsible for this increase in stocks, the uptake of these elements seems to be controlled mainly by the plant metabolism. The uptake was not proportional to the increase in soil concentrations. For example, the concentrations of $\mathrm{Zn}$ and $\mathrm{Cu}$ were seven- and six-fold as high in amended soils $(8 \mathrm{~N})$, respectively, as in the control soil (Table 1). The concentrations of $U$ and Th in maize grains were below the ICP-OES detection limit.

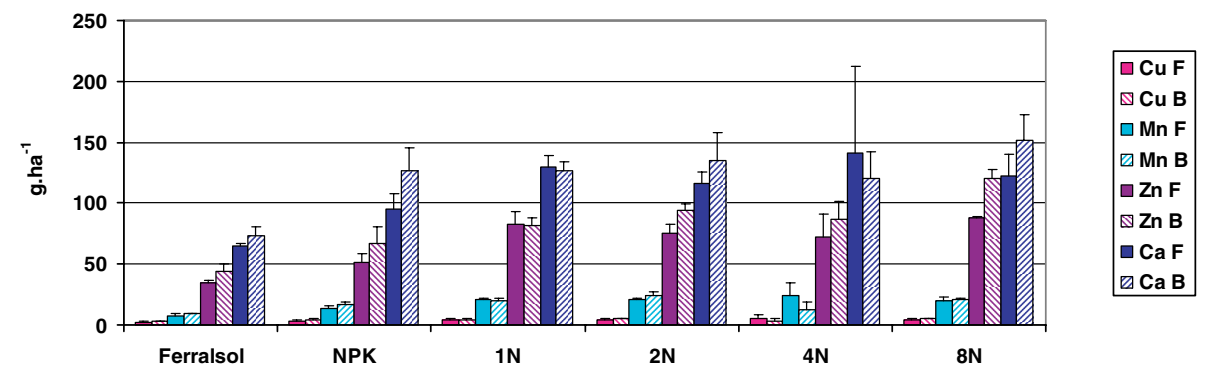

Figure 1. Stocks of $\mathrm{Cu}, \mathrm{Mn}, \mathrm{Zn}$, and $\mathrm{Ca}\left(\mathrm{g} \cdot \mathrm{ha}^{-1}\right)$ in maize after soil amendment with biosolids from Franca $(\mathrm{F})$ and Barueri (B) compared with control Ferralsol and NPK fertilization.

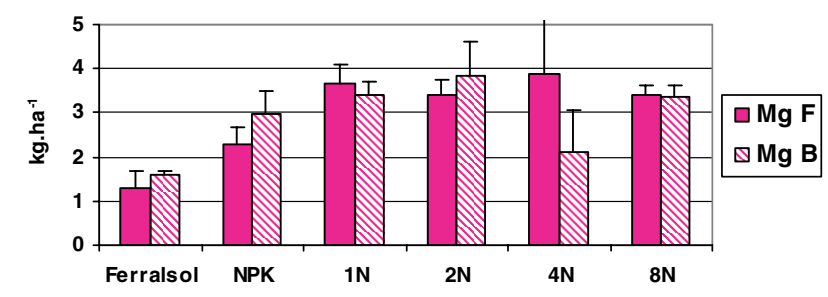

Figure 2. Stocks of $\mathrm{Mg}\left(\mathrm{kg} \cdot \mathrm{ha}^{-1}\right)$ in maize after soil amendment with biosolids from Franca $(\mathrm{F})$ and Barueri (B) compared with control Ferralsol and NPK fertilization.

It is important to note that despite the increase in root uptake after biosolid soil amendment, the concentrations of trace elements $\mathrm{Zn}, \mathrm{Cu}$, and $\mathrm{Mn}$ in all soil and grain samples analyzed were below to the Brazilian regulation limits (Table 2).

Table 2. Acceptable values $\left(\mathrm{mg} \cdot \mathrm{kg}^{-1}\right)$ of trace elements in agricultural soil and grains.

\begin{tabular}{lcccc}
\hline & $\begin{array}{c}\text { Intervention values for } \\
\text { agricultural soils [4] }\end{array}$ & $\begin{array}{c}\text { Mean value for soils } \\
\text { obtained in this study }\end{array}$ & $\begin{array}{c}\text { Intervention values for } \\
\text { maize [5] }\end{array}$ & $\begin{array}{c}\text { Mean value for } \\
\text { maize obtained in } \\
\text { this study }\end{array}$ \\
\hline $\mathrm{Mn}$ & No establish value & 296 & No established value & 3 \\
$\mathrm{Ni}$ & 70 & 34 & 5 & $<$ detection limit \\
$\mathrm{Cu}$ & 200 & 25 & 30 & 1 \\
$\mathrm{Zn}$ & 450 & 65 & 50 & 14 \\
$\mathrm{~Pb}$ & 200 & 21 & 8 & $<$ detection limit \\
\hline
\end{tabular}




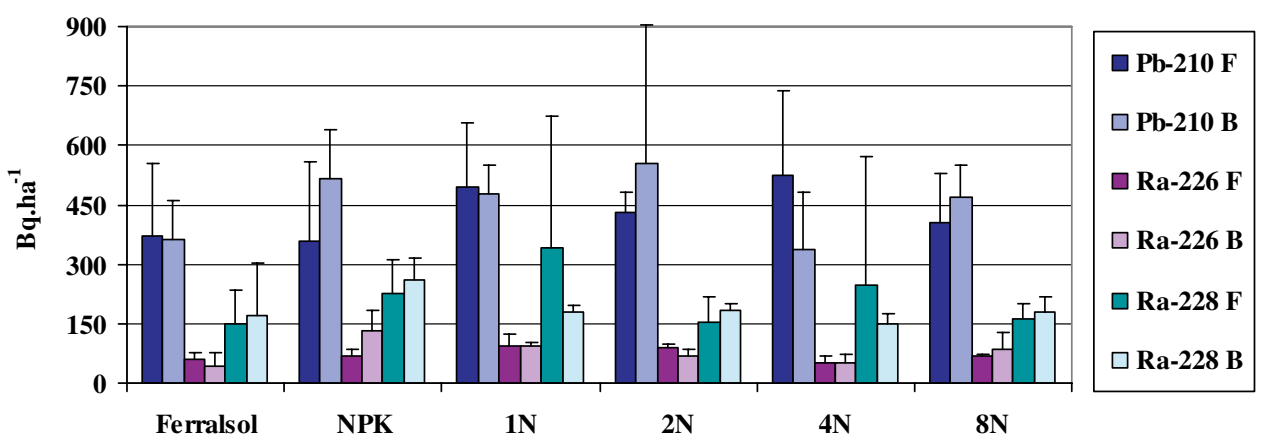

Figure 3. Stocks of natural radionuclides in maize $\left(\mathrm{Bq} \cdot \mathrm{ha}^{-1}\right)$ after amendment with Franca $(\mathrm{F})$ and Barueri $(\mathrm{B})$ biosolids compared with control Ferralsol and NPK fertilization.

In contrast, no significant increase in the stocks of natural radionuclides was observed in maize after biosolid soil amendment $(1 \mathrm{~N}, 2 \mathrm{~N}, 4 \mathrm{~N}$, or $8 \mathrm{~N})$ when compared with the control and NPK-amended soil (Figure 3). In addition, biosolid origin (B for Barueri and $\mathrm{F}$ for Franca in Figure 3) did not affect the stocks of the studied radionuclides in maize. Although plants can take up ${ }^{210} \mathrm{~Pb}$ through the roots and leaves [6], ${ }^{210} \mathrm{~Pb}$ and $\mathrm{Ra}$ show very low mobility in plant [7]. This means that their concentrations in maize are controlled mainly by the plant metabolism rather than by their concentrations in soil and their bioavailability. However, other crops, particularly those with edible parts in close contact with soil, like root and tuber vegetables, should show a different pattern. Viana [8] studied the root uptake of ${ }^{90} \mathrm{Sr}$ by radish and cabbage and observed a clearly higher soil-to-plant transfer factor than that of maize.

The soil-to-plant transfer factors (TF) of ${ }^{210} \mathrm{~Pb},{ }^{226} \mathrm{Ra}$, and ${ }^{228} \mathrm{Ra}$ for maize, independent of biosolids origin, are presented in Figure 4. Their average TF values were not different from the values for cereals in the literature [9-11].

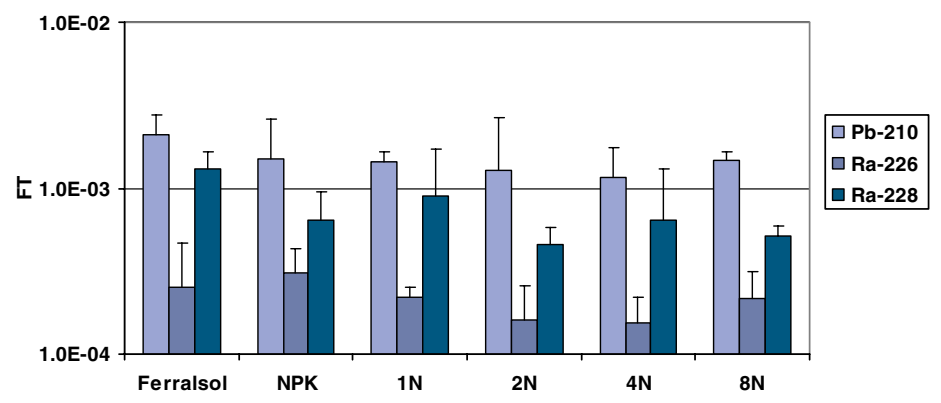

Figure 4. Soil-to-plant transfer factor after amendment with biosolid, independent of its origin, compared with control Ferralsol and NPK fertilization. (geometric mean; $n=6$ ).

According with the variance analysis, the soil-to-plant transfer factors of ${ }^{226} \mathrm{Ra}$, ${ }^{228} \mathrm{Ra}$, and ${ }^{210} \mathrm{~Pb}$ were not significantly influenced by either biosolid doses or origin or the interaction of these two factors (Table 3).

Comparison of the concentrations of ${ }^{210} \mathrm{~Pb},{ }^{226} \mathrm{Ra}$, and ${ }^{228} \mathrm{Ra}$ in Barueri and Franca to other biosolids are presented in Figure 5. The biosolid origin did not affect the radionuclide contents and the natural radionuclide concentrations of Barueri and Franca biosolids were very similar to those of Alegria and Brejo Comprido biosolids. Brasília and Jundiaí biosolids had low concentrations of ${ }^{226} \mathrm{Ra},{ }^{228} \mathrm{Ra}$, and ${ }^{210} \mathrm{~Pb}$, while Vila União biosolids had the highest concentrations. However, the concentration of ${ }^{210} \mathrm{~Pb}$ 
Table 3. Significance based on the variance analysis following the experimental design model (factorial $2 \times 6$ in 3 randomized blocks).

\begin{tabular}{lccc}
\hline Source of variation & ${ }^{210} \mathrm{~Pb}$ & ${ }^{226} \mathrm{Ra}$ & ${ }^{228} \mathrm{Ra}$ \\
\hline Sludge & $\mathrm{ns}$ & $\mathrm{ns}$ & $\mathrm{ns}$ \\
Dose & $\mathrm{ns}$ & $\mathrm{ns}$ & $\mathrm{ns}$ \\
Sludge $\times$ Dose & $\mathrm{ns}$ & $\mathrm{ns}$ & $\mathrm{ns}$ \\
$\mathrm{CV}$ & 55 & 39 & 12 \\
\hline
\end{tabular}

Ns, not significant; CV means coefficient of variation of the analysis of variance.

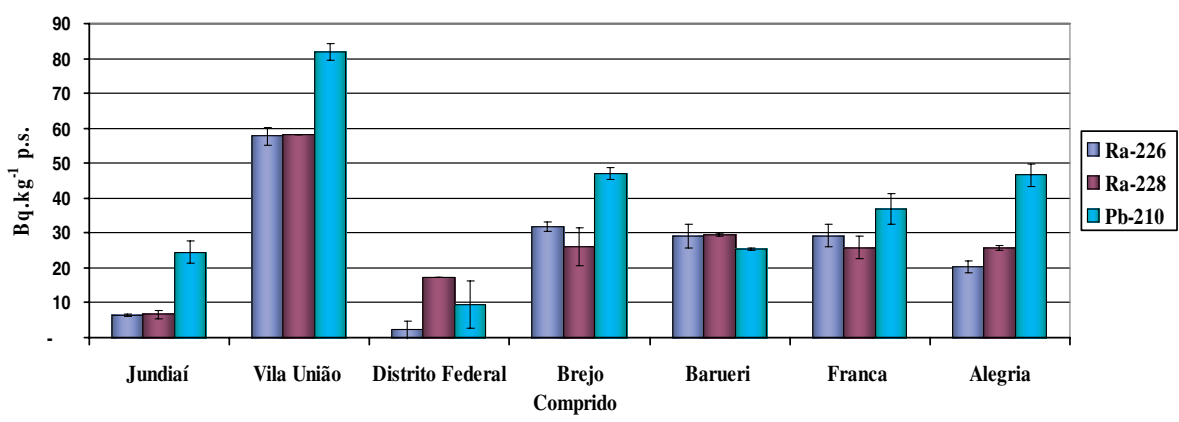

Figure 5. Natural radionuclide content in biosolids.

Table 4. Natural radionuclide concentrations in biosolids from United States of America and Brazil.

\begin{tabular}{cccccc}
\hline & \multicolumn{2}{c}{ USA [3] } & & \multicolumn{2}{c}{ Brazil (this study) } \\
\cline { 2 - 3 } \cline { 5 - 6 } & minimum & maximum & & minimum & maximum \\
\hline${ }^{210} \mathrm{~Pb}\left(\mathrm{~Bq} \cdot \mathrm{kg}^{-1}\right)$ & $<\mathrm{DL}$. & 481 & & 9 & 82 \\
${ }^{226} \mathrm{Ra}\left(\mathrm{Bq} \cdot \mathrm{kg}^{-1}\right)$ & $<\mathrm{DL}$. & 1739 & & 2 & 58 \\
${ }^{228} \mathrm{Ra}\left(\mathrm{Bq} \cdot \mathrm{kg}^{-1}\right)$ & 24.05 & 1406 & & 17 & 58 \\
\hline
\end{tabular}

DL, detection limit.

was five-fold as low as that of ${ }^{210} \mathrm{~Pb}$ reported for biosolids of the United States [3], and 30- and 24-fold as low, respectively, as those of ${ }^{226} \mathrm{Ra}$ and ${ }^{228} \mathrm{Ra}$ (Table 4).

\section{CONCLUSION}

The radionuclide concentrations in maize grains were not significantly influenced by either the applied biosolid doses, or biosolid origin, or the interaction of these two factors. These results may be explained by the very low content of these radionuclides in the studied biosolids. The increase in biomass due to biosolid soil amendment tends to dilute the concentration of elements not essential for the metabolism of maize. In conclusion, the cultivation of maize in biosolid-amended soil does not pose a radiological risk; however, if Brazilian regulations allow biosolid soil amendment for other crops than cereals, a more detailed study of the availability of natural radionuclides must be carried out.

\section{Acknowledgments}

The authors thank CNPq, FAPERJ and CNEN for the scholarship. 


\section{References}

[1] B.J. Alloway. Heavy metals in soils. (John Wiley \& Sons, New York, 1990).

[2] J. Hofmann, R. Leicht, H.J. Wingender, J. Worner. Radiological Impact Due to Wastes Containing Radionuclides from Use and Treatment of Water. (European Comission, Brussels, 2000.) Report EUR 19255.

[3] ISCORS. ISCORS Assessment of Radioactivity In Sewage Sludge: Radiological Survey Results and Analysis. (ISCORS, Washington, D.C., 2003).

[4] CETESB. Valores Orientadores para solos e águas subterrâneas no Estado de São Paulo: Anexo Único. (CETESB, São Paulo, 2005).

[5] ABIA. Compêndio da legislação dos alimentos. (ABIA, São Paulo, 1985).

[6] L.W. Ewers, G.J. Ham, B.T. Wilkins. Review of the transfer of naturally occurring radionuclides to terrestrial plants and domestic animals (National Radiological Protection Board, Oxon, 2003). Report NRPB W-49.

[7] H.T. Peterson, Jr. In Radiological Assessment: a Textbook on Environmental Dose Analysis edited by J.E. Till and H.R. Meyer (U.S. Nuclear Regulatory Comission. Washington D.C., 1983). Chapter 6.

[8] A.G. Viana. Avaliação do potencial de mobilidade do ${ }^{90} \mathrm{Sr}$ em solos brasileiros. Master dissertation (Instituto de Radioproteção e Dosimetria/CNEN, Rio de Janeiro, 2007).

[9] IUR. Fifth Report of the Working Group Soil-to-Plant Transfer Factors (RIVM, Bilthoven, 1989).

[10] P. Linsalata. Studies of Transport Pathways of Th, Rare Earth, ${ }^{228} \mathrm{Ra}$ and ${ }^{226} \mathrm{Ra}$ from soil to plants and Farm Animal (Institute of Environmental Medicine, New York, 1986). Report DOE/ER 60134-4.

[11] G.V. Cardoso. Avaliação dos Níveis de Exposição à Radiação nas Comunidades Circunvizinhas a Unidade de Mineração e Concentração de Urânio de Caetité - BA. Master dissertation (Universidade Federal Rural do Rio de Janeiro, Seropédica, 2004). 